\title{
Introduction to the Special Issue: Imagining a Link Between Local Activism and Political Transformation: Inventions from Russia and Eastern Europe
}

\author{
Karine Clément ${ }^{1,2} \cdot$ Anna Zhelnina ${ }^{3,4}$ \\ Published online: 3 June 2019 \\ C) Springer Science+Business Media, LLC, part of Springer Nature 2019
}

\begin{abstract}
This introduction aims to present the general outline of the special issue and to elaborate on the context against which most of the studies were conducted. We discuss the political, economic, social, and historical processes that contribute to shape Russia; this helps to understand local activism and protest in contemporary Russia. Since this context is relevant to all the papers, the readers would benefit from reading this introduction first. The second part of this paper introduces the contribution that the special issue makes to the study of activism and politics, with papers analyzing different aspects and kinds of activism in a variety of circumstances and settings. A central question common to all papers is the problem of politicization which is treated at the intersection between social and political inequalities, the experience of everyday life and political imagination.
\end{abstract}

Keywords Russia $\cdot$ Activism $\cdot$ Politics $\cdot$ Social Inequality $\cdot$ Imagination

This volume is an attempt to challenge the notions of activism and the political developed in academia in the Global North, as well as traditional theories of social movements. We do not exoticize Russia nor do we see it as a very special region that has nothing in common with the rest of the world. On the contrary, the authors share the feeling that new trends in the so-called "traditional democracies" can also be identified at the center of the former Soviet Empire-

Karine Clément

carine_clement@hotmail.com

Anna Zhelnina

azhelnina@gradcenter.cuny.edu

1 Centre d'études des Mondes russe, Caucasien et Centre-Européen (CERCEC), 54 Boulevard Raspail, 75006 Paris, France

2 Andrew Gagarin Center for Civil Society and Human Rights, Saint Petersburg, Russia

3 The Graduate Center, City University of New York, 365 5th Avenue, New York, NY 10016, USA

4 Saint Petersburg School of Social Sciences and Area Studies, Department of Sociology, National Research University Higher School of Economics, St.Petersburg, Russia 
trends such as the dismantlement of the welfare state, harsh neoliberal policies, and the rise of populism. We argue that Russia can be considered a place where tendencies that are hidden or half-hidden in the polite, "politically-correct" West show up more brightly.

The authors of this volume - who come from different countries and sociological sub-fieldsshare a desire to learn more about new trends and problematics in the political evolution of contemporary societies from the vantage point of Russia and Eastern Europe. The decision to work together on this publication was also motivated by the professional synergies and friendships that emerged from several cross-cultural collaborations. This special issue is the result of regular intellectual exchanges between young and established scholars - both Russians and non-Russians - who wanted to explore the apparently contradictory relationship between local, or grassroots, activism, which seems to be growing, and state-level politics, which seems to be shrinking.

\section{The Russian Context}

Before we can turn to the topics of this special issue, we need to outline the current political and social context in Russia. Politically, Russia is often categorized as a country with elements of both authoritarianism and democracy: a "hybrid regime" (Diamond 2002) or a case of "electoral authoritarianism" (Gel'man 2014; Schedler 2013). Although the ideal democracy does not seem to exist anywhere in the real world, it is possible to say that Russia is quite far from the democratic ideal. However, the tendency to see authoritarian countries in black and white does not help to better understand the realities of authoritarianism, which, from the point of view of everyday life, are rather "boring and tolerable" (Pepinsky 2017). Political freedoms such as freedom of speech, equality before the law, and freedom of assembly are limited, but citizens still have access to diverse political opinions and information. Political repression occurs, but not on a massive scale, and when it does occur, it lacks widespread social resonance.

A less obvious but nonetheless critically important feature of Russian authoritarianism is the ideological chaos that prevails in people's minds. Resulting from both the rejection of communism and the hegemony of neoliberal capitalism, notions of right and left do not make any sense in this society, and an individual may embrace values that belong simultaneously to opposite ideological traditions. There are no widely recognized political cleavages along any ideological lines. The labels that the media and intellectuals often use (democracy versus authoritarianism, liberalism versus conservatism, or elites versus the loyal masses) do not reflect the contradictory and more nuanced reality. In truth, most people partially belong to all the "camps" and support seemingly contradictory ideas: it is only possible to make sense of such heterogeneous views when one pays attention to the embodiment of these concepts in people's everyday life. Most people, for instance, share a disillusionment with democracy, which is associated with all the social problems of the 1990s, the "hard times" after the collapse of the Soviet Union. Still, few would reject democracy as such.

The next widespread feature of Russian politics is mass support for the leader, President Vladimir Putin, who appears to be more a symbol of the nation than a political official. Mass support for Putin is neither irrational nor symptomatic of a "Russian" affinity for authoritarianism. His popularity is rooted in the connection between democratic disenchantment and profound social disarray.

In the economic realm, people in Russia have been subjected to two harsh waves of ultraliberal capitalist reforms. In the 1990s, the first wave of such reforms - known as "shock therapy" (the brutal implementation of the structural adjustment model required by the International Monetary Fund) - led to unprecedented economic decline and breakdown of social ties, which had a tremendous impact on people's everyday life. At that time, Russia 
provided a particularly attractive testbed for experimenting with dogmatic neoliberal reforms, since it was widely assumed - and the idea was actively promoted by the new ruling elitethat the Soviet system had to be destroyed in order to build a prosperous "market democracy." As a result, incomes of the majority of the population plummeted. According to official Russian State statistics, between 1991 and 1992, real incomes dropped by 43.7\%. They recovered to reach pre-reform levels only in 2005 . Wages fell even more drastically, while wage arrears grew explosively over the 1990s. According to Gimpelson and Kapelyushnikov (2007), from 1991 to 1998, real wages lost cumulatively around two thirds of their value.

Both the economic situation and material living conditions have improved since the beginning of the 2000s, in the period corresponding to Putin's presidency. During the 2000s, real wages and pensions recovered, and poverty fell by half. Many people experienced relief from the day-to-day struggle for survival and recovered a sense of having some foundation under their feet. However, a new stage in neoliberal reforms began, with Putin's government aiming this time to restructure the social welfare system. A flat rate of income taxation (13\%) was adopted in 2001. The new labor code implemented in 2002 improved the employers' position while the employees' position deteriorated, especially with regard to their ability to self-organize in independent trade unions and to coordinate strikes. Later in the 2000s, the legislation on housing and urban and environmental issues was reformed. This increased the cost of residents' utilities and housing maintenance while opening the path to the privatization of communal services, housing, and land. The course chosen by the government under the influence of the World Bank and the World Trade Organization focused on price deregulation and privatization. Thus, as a whole, Russia has come to belong to the neoliberal capitalist world.

In the social realm, two main features of Russian society have to be highlighted. First, the high degree and spread of social, labor, and material precarization - which was all-pervading in the 1990s - continues to destabilize people and break down solidarities. This is a massive worldwide trend in neoliberal capitalist societies, abundantly analyzed in the literature (Boltanski and Chiapello 1999; Breman and van der Linden 2014; Sennet 1998; Standing 2011); but it is particularly widespread in Russia, even though it is not acknowledged as a political or social problem. Second is the rise of social inequality - which is also not peculiar to Russia, although Russian society stands out because of the tiny proportion of its citizens who are middle class; the majority of its population are poor, in a precarious position, or at risk of poverty, while those at the top are immensely rich. According to the Credit Suisse Global Wealth Report, Russia has the highest level of inequality of all countries: "the top decile of wealth-holders owns $89 \%$ of all household wealth in Russia. This is significantly higher than any other major economic power: the corresponding figure is $78 \%$ for the United States, for example, and 73\% for China" (Credit Suisse Global Wealth Report, 2016). The degree of geographical inequality is also high and increasing: the countryside and small towns remote from the urban centers face decay (deindustrialization, dismantlement of public infrastructure, depopulation), while most of the nation's wealth is concentrated in big central cities such as Moscow and to some extent St. Petersburg.

History, of course, has shaped Russia into a unique country that has experienced many twists and turns in a relatively short period, particularly since the collapse of the Communist regime and the breakdown of the Soviet Union. At different periods in their lives, Russian people have experienced multiple crises and upheavals: the collapse of one huge country (the Soviet Union) and the emergence of another (Russia); the substitution of the communist ideology by market democracy; brutal rises and falls in material and social status; moral inversion; several economic collapses; and both inter-state wars and the threat of civil wars. The result is an atomized society where people share hardly any significant patterns of socialization. Almost everyone has to 
produce their own synthesis of contradictory layers of life experiences. This makes it difficult to arrive at a clear picture of the society one lives in, and hinders the building of solidarities and common visions.

Despite this, Russian society has never been totally apathetic. Social movements that emerged during the Perestroika (National Fronts, informal clubs and networks, workers' movements) are well known for their role in the collapse of the Soviet regime. After the "victory of democracy," most activists from these movements accepted the first President's (Boris Yeltsin's) regime and quit protesting. The opposition to the new president's regime was crushed during the violent escalation of a political conflict between pro-President and pro-Parliament forces in October 1993, when Yeltsin sent tanks to the parliament building, which was being defended by opposition activists.

Civic mobilization was always part of Russian political reality, although it was not widespread enough to resist the capitalist market reforms and the ensuing hardships of the 1990s (Burawoy 1999). In the first post-Soviet decade, labor protests grew and eventually reached a high level of politicization and radicalism: by the late 1990s, the workers' occupation of plants, the highly resonant miners' strikes, and blockades of the Trans-Siberian railway in May-June 1998 had led to demands for Yeltsin's resignation. However, the ensuing change in president and the devaluation of the ruble - which revitalized the economy — put an end to these mobilizations.

After a brief silence due to the economic improvement and restoration of the state that occurred under Vladimir Putin's presidency, civic mobilization exploded again from the mid2000s, with people protesting against cuts to welfare, poor and expensive public utilities, the deterioration of housing, the destruction of local green spaces, low wages, and the closure of local schools and hospitals. With some exceptions - such as the massive protests against the reform of the social benefits system in 2005-people most actively engaged in grassroots mobilization, i.e., diffuse, local activism that is rooted in the daily lives of its participants and seeks to address particular, narrowly defined social problems. Analysis of the mobilizations of the 2000s (Clement et al. 2010) demonstrates that the principal problem facing Russian civic life is not the mythical "Russian quiescence," but rather the lack of adequate representation of these social struggles in media and intellectual discourses. Such struggles are often considered either old-fashioned and reactionary (especially in the 1990s) or too small, insignificant, paternalistic, and apolitical (the dominant view during Putin's era).

Unlike these grassroots initiatives and labor protests, the 2011-2012 movement "For Fair Elections" (or Bolotnaya movement) gained high visibility in the media and credibility among intellectuals. The movement For Fair Elections (also renamed the "anti-Putin" or "oppositional" movement by the liberal media) was relatively homogenous and mostly involved highly educated liberal professionals in Moscow and St. Petersburg. It attracted few people from other regions or of lower social status. One of the effects of this movement has been the renewal of academic interest in studying social movements in Russia (Erpyleva and Magun 2014; Bikbov 2012; Volkov 2012, Smyth, Sobolev, \& Soboleva, 2013; Gabowitsch 2016; Greene 2014; Ross 2016). By the end of 2012, this so-called oppositional movement began to shrink, but grassroots initiatives and labor protests continued to develop all around the country - in large part because of the ongoing economic crisis. ${ }^{1}$ Some of the papers in this issue address the For Fair Elections movement, as well as the local initiatives and electoral mobilizations that derived from it. Other papers put the emphasis on grassroots movements that are not directly connected to the movement

\footnotetext{
${ }^{1}$ Following the global economic crisis of 2008-2009, the economic crisis in Russia has continued. This is due to a fall in the ruble and in oil and gas prices, as well as sanctions and counter-sanctions announced after Russia's annexation of the Crimea.
} 
For Fair Elections; these involve a different kind of mobilization process and their participants have more diverse socio-professional profiles. Whatever their empirical focus, all contributions to this volume prove the inaccuracy of the stereotype of Russian apathy. In this special issue, we offer a nuanced view of activism, showing that it can take many forms and has many different meanings that cannot be reduced to simple patterns. The collective initiatives analyzed in this volume cannot easily be classified as either "pro-" or "anti-" Putin, as either dissenting or loyal. Rather than being "either/or," activism in the post-Soviet area (and surely beyond) is more typically "both/and," being at once practically oriented and oppositional, supportive in one sense and resisting in another (Jacobsson 2015).

Activism does not necessarily mean politicization in the usual sense: there is a strong tendency among grassroots activists themselves - as well as among the political and intellectual elites - to try to uncouple local, urban, economic, or social struggles from the political realm, which is understood as the sphere of government. However, there are also other tendencies towards different kinds of politicization that the authors of this issue see in local activism or in everyday settings. These tendencies are analyzed using different terms and with different approaches: as "civic politics" (Zhuravlev, Savelyeva \& Erpyleva 2019); or "pragmatic politics" (Clement \& Zhelnina 2019); or the pragmatic experience of "big politics" by local activists (Eliasoph \& Clément 2019).

\section{The Contribution of the Special Issue}

Thus, this special issue partially dismantles the myth of an apolitical Russian society. As many of its contributors point out, the forced politicization of soviet times, followed by the market ideology and economic destabilization of the post-soviet period, have led to the population's mass rejection of politics and its retrenchment in the immediate sphere of home and work. Thus, apoliticism would come as no surprise in Russia. However, the reality is not so simple. First, there is no evidence that conclusively shows whether or not Russian society is more depoliticized than any other society. The literature abounds on the crisis of politics and depoliticization even in traditional democracies (Rosanvallon 2006; Eliasoph 1998; Putnam 2000). Second, there is also an opposite tendency in Russia towards greater politicization. Not only did the nationwide 2011-2012 movement "For Fair Elections" politicize some of its participants; it has also given rise to multiple new or partially new local activist groups that work on linking "small (or real) deeds" to politics (Zhuravlev, Savelyeva \& Erpyleva 2019).

Another politicizing force has been the nationalist sentiment and national pride that has increased following a surge in the Russian authorities' patriotic and nationalist rhetoric since 2014. However, this nationalistic (relative) revival cannot be reduced to "rallying round the leader" (Kolstø and Blakkisrud 2016). Ethnographic studies in the post-communist area show that there are many ways to be a patriot and to perceive the nationalist project (Daucé et al. 2015; Goode 2016; Hemment 2015; Brubaker et al. 2006). They also show that populism has become one of the few ideologies available to disenfranchised populations when they try to make sense of their discontentments (Kalb 2009; Clément 2019). Thus, Putin's populist discourse may lead to many unsung people from the wide fringes of society recovering a sense of self-worth. This does not necessarily entail blind support for the leader: support for Putin should not be interpreted as demonstrating the mythical Russian authoritarianism and conformism. The decision to support Putin may be both conscious and informed — one made despite all the criticism. Encountering some of these new means of politicization, we argue that it is crucial to analyze politics from below, from the perspective of people unwilling to acknowledge 
that they are talking or doing politics. There is certainly no definition of the political that we all agree on in this special issue. However, there is a common concern not to limit our definition of politics to institutions and governments, and to look beyond what we might consider "good" politics that corresponds to our democratic or civic ideals. Thus, there is a common search for any signs of the political manifested in what people do or say in different settings. What kind of signs? None of us define their character prior to observing the complex reality of concrete actions or utterances. Empirical fieldwork comes first. This means that there is no content that we pre-define as political for normative reasons. Very broadly, signs indicate politicization if they suggest that new ways of imagining a better shared future are being opened up.

In order to identify these signs, the best approach to adopt is the ethnography of politics (Luhtakallio and Eliasoph 2014). Although not all the contributions in this issue are fully ethnographic, they do share a sensitivity to real people in real settings, with all the contradictions and ambiguities of their lived experience. While this is no guarantee of accurate interpretation, it is a necessity if one does not want to encapsulate the political in any normative or moral definition.

In line with this approach, most authors promote a form of sociology that focuses on lived experience, practices, meaning-making, and concrete interactions. The articles in this issue are influenced by phenomenology, pragmatic sociology (Thévenot 2001), and cultural sociology (Silber 2003). However, while this special issue pays close attention to the micro-level and to agency, this does not mean that the question of inequalities of power is ignored. On the contrary, this is a central question-one that this issue's authors address by describing the many different ways in which people in different contexts struggle against unequal power relations, and may even end up regaining some kind of power themselves.

The theoretical contribution of this special issue is to offer alternative ways of conceptualizing the political and to better understand processes of politicization. Politicization is shown, on the one hand, to be a process that is strongly shaped by the experiences of everyday life, people's diverse trajectories and groups' particular styles (Lichterman and Eliasoph 2014). On the other hand, the politicization process is neither linear nor univocal, and faces strong obstacles - among which social and political inequality is the most significant. However, even in contexts where there is a high degree of inequality and a low degree of democracy - as there is in Russia nowadays - people can rely on their everyday experience and their social imaginary to confront these obstacles and expand their political imagination. To show how this can happen, the articles in this issue consider multiple perspectives on the political: the perspective of local grassroots initiatives, of nationwide movements, of people without any activist experience, and of participants in local elections. Besides the comparison between different "Russian" cases afforded by this presentation of multiple perspectives, a comparative dimension is also provided by those authors who look at politics in other countries through the lens of problematics that shine brightly in Russia.

Another important feature of this volume is the diachronicity of many of the studies it contains. Its articles reveal the dynamics of politicization and depoliticization, dealing with disrupted individual trajectories, with the ups and downs of movements and grassroots initiatives, with the changing mood of the same individual in different settings, or even at different moments in the same conversation.

Most authors study both the move from the local and particular towards the supralocal and general and the reverse move from the general to the particular. They analyze the shift from engagement to disengagement to re-engagement, from loyalty to dissent and back again — and 
so on. These movements are not mutually exclusive and can coexist within one group or even within one person. Hence, this special issue shows that politicization and depoliticization are part of the same continuum, and the meanings attached to them are constantly changing.

This special issue thus participates in the current discussion about reimagining the political. It proceeds not from theoretical questions, but rather from practices and meanings that show up if we attentively look out for them - and it does so without reducing the many kaleidoscopic and contradictory forms of politicization to an insignificant mess.

Maybe more than any other part of the world, post-communist Russia has experienced the crisis of ideologies - the blurring of the boundaries between right and left—along with all the other implications of the neo-liberal democratic order that prevails globally and leads to democratic disenchantment and populist or nationalist enchantment. Thus, by looking more closely at how politics is still able to operate in such conditions, this special issue could contribute to exploring new paths towards the political.

Acknowledgments The issue has been made possible thanks to the support of the Gagarin Center for Civic Society and Human Rights in St. Petersburg.

\section{References}

Bikbov, A. (2012). The methodology of studying 'spontaneous' street activism (Russian protest and street camps, December 2011-July 2012). Laboratorium, 2, 275-284.

Boltanski, L., \& Chiapello, E. (1999). Le nouvel esprit du capitalisme. Paris: Gallimard.

Breman, J., \& van der Linden, M. (2014). Informalizing the economy: the return of the social question at a global level. Dev Chang, 45, 920-940.

Brubaker, R., Feischmidt, M., Fox, J., \& Grancea, L. (2006). Nationalist politics and everyday ethnicity in a Transylvanian town. Princeton and Oxford: Princeton University Press.

Burawoy, M. (1999). The great involution: Russia's response to the market. http://burawoy.berkeley. edu/Russia/involution.pdf. Accessed May 14, 2019

Clément, K. (2019). Social mobilizations and the question of social justice in contemporary Russia. Globalizations, 16(2), 155-169.

Clément, K. \& Zhelnina, A. (2019). Beyond Loyalty and Dissent: Pragmatic Everyday Politics in Contemporary Russia. International Journal of Politics, Culture and Society, https://doi.org/10.1007/s10767-019-9319-0

Clement et al. (2010). Ot obyvatelej k aktivistam: Zaroždaûŝiesâ social'nye dviženiâ v nynešnej Rossii [From ordinary people to activists: Emerging social movements in contemporary Russia]. Moscow: Tri Kvadrata.

Credit Suisse Global Wealth Report (2016). Retreived from: https://www.credit-suisse. com/corporate/en/research/research-institute/global-wealth-report.html. Accessed 13 May 2017.

Daucé, F., Laruelle, M., Le Huérou, A., \& Rousselet, K. (2015). Introduction: what does it mean to be a patriot? Eur-Asia Stud, 67(1), 1-7.

Diamond, L. J. (2002). Thinking about hybrid regimes. J Democr, 13(2), 21-35.

Eliasoph, N. (1998). Avoiding politics: How Americans produce apathy in everyday life. Cambridge: Cambridge University Press.

Eliasoph, N. \& Clément, K. (2019). Doing Comparative Ethnography in Vastly Different National Conditions: The Case of Local Grassroots Activism in Russia and the United States. International Journal of Politics, Culture and Society, https://doi.org/10.1007/s10767-019-9325-2

Erpyleva, S., \& Magun, A. (Eds.). (2014). Politika apolitičnyh. Graždanskie dviženiâ v Rossii 2011-2013 godov [The politics of the 'apolitical:' Citizens movements in Russia, 2012-2013]. M: Novoe literaturnoe obozrenie.

Gabowitsch, M. (2016). Protest in Putin's Russia. Cambridge: Polity Press.

Gel'man, V. (2014). The rise and decline of electoral authoritarianism in Russia. Demokratizatsiya, 22(4), 503.

Gimpelson, V., \& Kapelyushnikov, R. (2007). Zarabotnaâ plata v Rossii. In Èvoluciâ i differenciaciâ [wages in Russia: Evolution and differentiation]. Moscow: State University High School of Economics.

Goode, J. (2016). Everyday patriotism and Putin's foreign policy. In PONARS Eurasia Workshop on Russia in International Affairs. University of Bath. 
Greene, S. (2014). Moscow in Movement: Power and Opposition in Putin's Russia. Palo Alto: Stanford University Press.

Hemment, J. (2015). Youth politics in Putin's Russia: producing patriots and entrepreneurs. Bloomington: Indiana University Press.

Jacobsson, K. (Ed.). (2015). Urban grassroots movements in Central and Eastern Europe: Introduction. Farnham: Ashgate.

Kalb, D. (2009). Conversations with a polish populist: Tracing hidden histories of globalization, class, and dispossession in Postsocialism (and beyond). Am Ethnol, 36(2), 207-223.

Kolstø, P., \& Blakkisrud, H. (Eds.). (2016). The new Russian nationalism: imperialism, ethnicity and authoritarianism 2000-2015. Edinburgh: Edinburgh University Press.

Lichterman, P., \& Eliasoph, N. (2014). Civic action. Am J Sociol, 120(\#4), 798-863.

Luhtakallio, E. \& N. Eliasoph. 2014. Ethnography of politics and political communication: studies in sociology and political science. In The Oxford Handbook of Political Communication, edited by Kate Kenski and Kathleen Hall Jamieson. Retrieved from https://doi.org/10.1093/oxfordhb/9780199793471.013.28. Accessed April 20, 2016.

Pepinsky, T. (2017). Everyday Authoritarianism Is Boring and Tolerable. Retrieved April 11, 2018, from https://tompepinsky.com/2017/01/06/everyday-authoritarianism-is-boring-and-tolerable/.

Putnam, R. D. (2000). Bowling alone: the collapse and revival of American community. New York: Simon and Schuster.

Rosanvallon, P. (2006). La contre-démocratie: la politique à l'âge de la défiance. Paris: Seuil.

Ross, C. (Ed.). (2016). Systemic and non-systemic opposition in the Russian Federation: civil society awakens? (p. 2016). London and New York: Routledge.

Schedler, A. (2013). The politics of uncertainty: Sustaining and subverting electoral authoritarianism. Oxford: OUP.

Sennet, R. (1998). The corrosion of character. The personal consequences of work in the new capitalism. New York: WW Norton.

Silber, I. F. (2003). Pragmatic sociology as cultural sociology beyond repertoire theory? Eur J Soc Theory, 6(4), $427-449$.

Smyth, R., Sobolev, A., \& Soboleva, I. (2013). Patterns of discontent: identifying the participant core in Russian post-election protest. Paper prepared for the Russia's winter of discontent: taking stock of changing statesociety relationships conference, September 6-7, 2013. Sweden: Uppsala University. Retrieved from http://www.ires.uu.se/digitalAssets/254/c_254668-1_3-k_discontentconfsmythpatternsofdiscontent.pdf. Accessed 14 May 2019.

Standing, G. (2011). The precariat: the new dangerous class. In London. New York: Bloomsbury Academic.

Thévenot, L. (2001). Pragmatic regimes governing the engagement with the world. In K. Knorr-Cetina, T. Schatzk, \& E. Savigny Eike (Eds.), The practice turn in contemporary theory (pp. 56-73). London: Routledge.

Volkov, D. (2012). The protesters and the public. J Democr, 23(3), 55-62.

Zhuravlev, Savelyeva \& Erpyleva (2019). The cultural pragmatics of an event: the politicization of local activism in Russia, International Journal of Politics, Culture and Society, this volume.

Publisher's Note Springer Nature remains neutral with regard to jurisdictional claims in published maps and institutional affiliations. 